\title{
ELECTROPHORETIC AND IMMUNOELECTROPHORETIC CHARACTERISTICS OF IgG AS A CONSTITUENTS OF PEG PRECIPITABLE IMMUNE COMPLEXES IN PRERUMINANT CALVES' SERA
}

FRATRIĆ NATALIJA*, ILIĆ VESNA**, MILOŠEVIĆ-JOVČIĆ NADEŽDA** and STOJIĆ V*

*University of Belgrade, Faculty of Veterinary Medicine, Serbia

**University of Belgrade, Institute for Medical Research, Serbia

(Received 21 th September 2009)

Preruminant calves encounter numerous antigens, and formation of immune complexes is necessary for antigens elimination. The capability of immunologically immature calves to form immune complexes has not yet been studied in detail. For immune complexes studies, selective precipitation by PEG was performed, in combination with agarose gel electrophoresis and immunoelectrophoresis, with an aim to determine some properties of IgG, as constituents of immune complexes. In our previous work it was shown that the level of PEG precipitable immune complexes increased in the period from birth to 48- hours of life, decreased at day 10, increased in one month old animals, and after that, stayed unchanged until $4^{\text {th }}$ month of age. Electrophoretic and immunoelectrophoretic analysis showed that until one motnth of age, calves' sera and PEG precipitates contained only one part of IgG molecules which corresonded to fast, anionic $\gamma$ globulins. Although at the age of one month, preruminant calves' sera contained all molecular forms of IgG molecules present in the sera of adult cattle, only one part of serum IgG (fast, anionic lgG) was precipitated by PEG. In older calves, all molecular forms of serum IgG had the capacity to form PEG precipitable immune complexes. Presented data, as well as the results of our previous work, can be used as parameters with reference to physicochemical and immunochemical characteristics of IgG immune complexes of preruminant calves under pathological conditions.

Key words: calves, IgG, immune complexes, PEG assay

\section{INTRODUCTION}

The immune system of newborn calves encounters numerous antigens that can originate from the environment, food or commensal bacteria in the digestive system (Tizard, 1996). Formation of immune complexes (IC), composed of antigen and antigen specific antibody, is necessary for the elimination of these antigens. Early in their life, calves are protected by maternal immunoglobulins, mostly of lgG1 isotype (Korhonen et al., 2000), passively transferred from the 
colostrum, and later by endogenously produced antibodies (Weaver et al., 2000). The capacity of calves' serum IgG, irrespective of their origin (maternal or endogenously produced), to form IC has not been appreciated yet. It may be of relevance since IC can act as a stimulator or inhibitor of various immune reactions, by specific interactions with immunoglobulins' receptors expressed on many cells of the immune system (Abbas et al., 2007). Bovine IC in different age categories, under physiological conditions, has not yet been studied in detail, and especially characteristics of IgG antibodies as potential constituents of IC are almost unknown. Analysing the circulating IC in preruminat calves could be of great importance, knowing that the increasing level of circulating IC is detectable in a variety of autoimmune diseases, microbial infections and malignancies, both in man and different animal species (Schifferli and Taylor, 1989; Abbas et al., 2007; Nydegger, 2007), and the determination of circulating IC level is necessary for detection and follow-up of disease.

In this study, PEG precipitation assay was used for the detection of IC in calves' sera. It represents a widely used method for routine determination of circulating IC level (Lock and Unsworth, 2000) that allows both, the quantification of circulating IC, and the analyses of the composition of PEG precipitable material. We showed that heat aggregated bovine serum IgG, used as in vitro model of IC, was PEG perceptible (Fratrić et al., 2006), and we have considered PEG assay as adequate for quantitative and qualitative determination of IgG immune complexes at different time points, during early life of calves. In the present, as well as in our previous work (Fratrić et al., 2006), it was shown that IC level fluctuates with age of the animals. Using methods of electrophoresis and immunoelectrophoresis it was shown that until calves are one month old; only one part of serum IgG has the capacity to form PEG precipitable IC, whereas in older calves, as well as in adult cattle, all molecular forms of IgG have the capacity to form IC. Obtained data enabled us to detect the preruminant calves' circulating IC, and to partially characterize IgG as constituent of the IC. These values, in combination with the clinical parameters, could provide a method for early diagnosis of infectious disease and systemic immunologic disorders in preruminant calves.

\section{MATERIAL AND METHODS}

Animals. A group of 13 healthy Holstein-Friesian calves aged from 6 hours to 4 months was used for monitoring the changes of circulating IC levels with age. A control group of 13 healthy Holstein-Friesian cows were also included in this study. All animals were from the farm "Kovilovo 2", PK Belgrade.

Blood samples. Blood was taken from the jugular vein of 6-, 24-, and 48hours, 10-days 1, 2, 3 and 4- month old calves. Blood from cows was taken one month after calving. The serum was separated after spontaneous coagulation of blood at room temperature, and centrifugation at $3000 \mathrm{rpm}$.

PEG precipitation assays. Polyethylene glycol (PEG) precipitation assays (Nikolić et al., 1981) were used for the quantification of immune complexes and the analysis of PEG precipitated material. Briefly, 3\% PEG (MW 6000) (Sigma, 
Acta Veterinaria (Beograd), Vol. 60, No. 2-3, 155-164, 2010.

Fratrić Natalija et al.: Electrophoretic and immunoelectrophoretic characteristics of

IgG as a constituents of PEG precipitable immune complexes in preruminant calves' sera

Taufkirchen, Germany) was added to the serum samples, and after two hours of incubation on $4^{\circ} \mathrm{C}$, the precipitated proteins were redissolved in distilled water. Optical density (OD) of the redissolved PEG precipitate sample was read at $350 \mathrm{~nm}$, with an Ultrospec 3300pro spectrophotometer (Amersham Bioscience, Uppsala Sweden).

Agarose gel electrophoresis. Agarose gel electrophoresis performed according to Johansson (1972) was used for analysis of protein composition of pools of bovine sera, and pools of PEG precipitates of every examined age.

Immunoelectrophoresis. Immunochemical identification of total IgG or IgG1 subclass in the pools of bovine sera and in the pools of PEG precipitates were performed by immunoelectrophoresis (Scheidegger, 1955) using specific antisera to IgG bovine and IgG1 molecules (INEP-Zemun, Serbia).

\section{RESULTS}

Electrophoretic mobility of proteins of the calves blood sera and PEG precipitable IC. In our previous work we showed that in preruminant calves' sera PEG precipitates' OD values fluctuated with age (Fratrić et al., 2006). It significantly increased in the period of 6 - to 24 hours $(p=0.002)$, and stayed at a similar level until 48- hours of life. On 10th day, PEG precipitates' OD levels decreased, but due to high level of individual variation, the observed change was statistically insignificant. OD level increased again in one month old animals ( $p=$ 0.002 ), and remained unchanged until 4th month of age. After determination of OD level of PEG precipitate in each individual sample, pools of calves' sera and pools of PEG precipitable IC were prepared, and analyzed by agarose gel electrophoresis (Figure 1). Pool of cattle sera was used as control.

In the serum of $6 \mathrm{~h}$ old calves, fraction of slow, cationic fraction of $\gamma$ globulins was absent, and the fraction of fast $\gamma$ globulins was of very low intensity. Fast $\gamma$ globulins were only one $\gamma$ globulin fraction detected in sera of 6-, 24-, and 48 hours, and 10 days old calves. The intensity of this fraction increased in the sera of 24 and 48-hour-old calves, but in the sera of 10-day old animals, its intensity decreased. In one month old calves, the fraction of slow $\gamma$ globulin appeared, and its intensity, as the intensity of the fast $\gamma$ globulin fraction, increased with the age of animals. After one month of age, the proteinograms, with slow and fast $\gamma$ globulin fractions, corresponded to the proteinograms of adult cattle sera. For other fractions (albumins, $\alpha$ and $\beta$ globulins), differences in electrophoretic mobility between preruminant calves and adult cattle sera were not shown.

In IC isolated from sera of calves and adult cattle by PEG precipitation, all serum protein fractions present in the corresponding sera (albumins, $\alpha, \beta$, and $\gamma$ globulins) were detected, but densitometric analysis showed that the precipitation of $\gamma$ globulins was selective, and it was not accompanied by precipitation, in the same percentage, of other serum proteins (data not shown). In all age groups, as a constituent of IC, fractions of fast $\gamma$ globulins appeared. Although the cationic part of $\gamma$ globulins appeared in sera from one month old cattle, this $\gamma$ globulin fraction was not PEG precipitable. Slow, cationic $\gamma$ globulin, at low concentration, 
appeared only in the PEG precipitates isolated from sera of calves older then one month, but the intensity of this fraction was lower than in adult cattle.

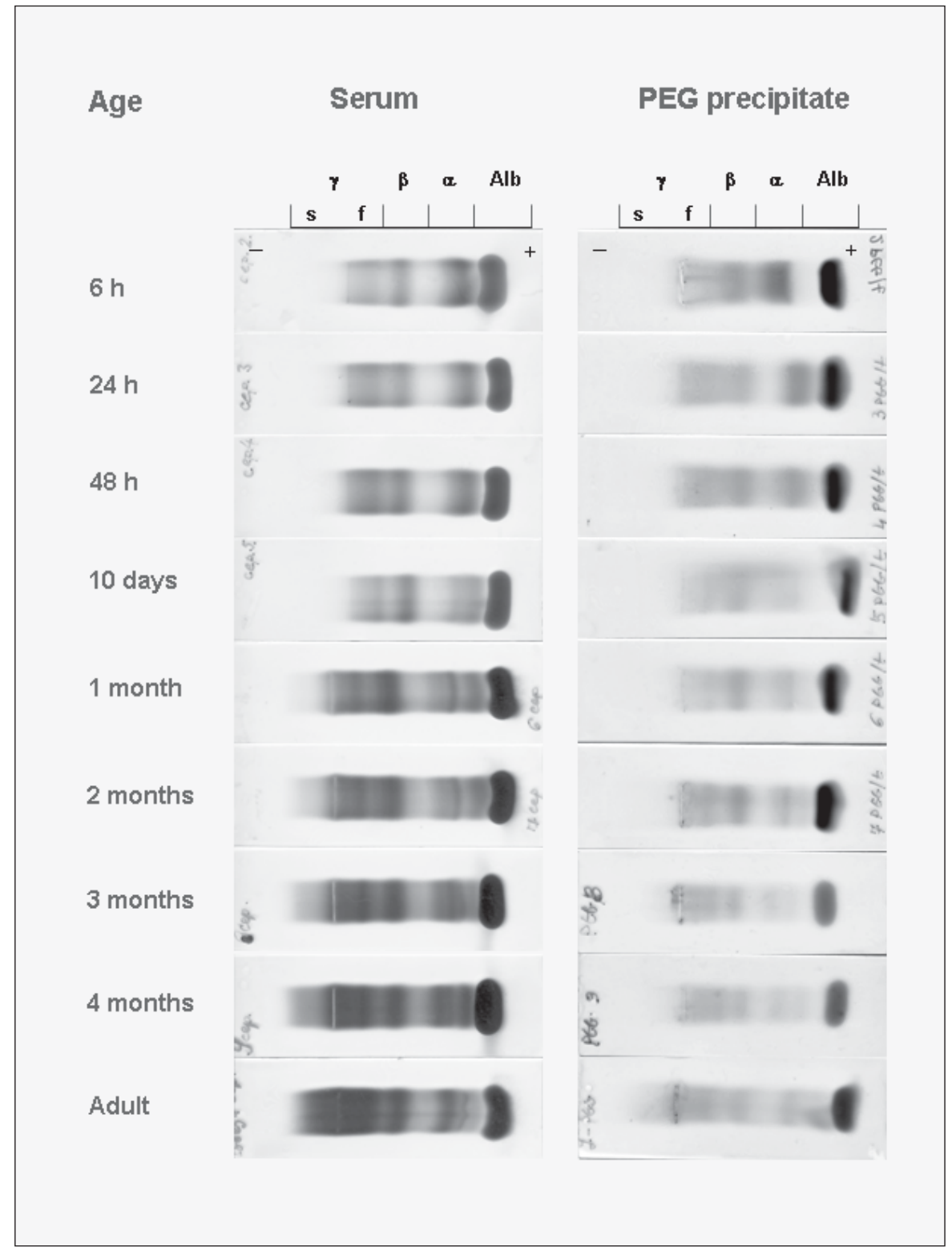

Figure 1. Agarose gel electrophoresis of calves' sera and PEG precipitated IC Alb - Albumin; $\alpha-\alpha$ globulin; $\beta-\beta$ globulin; $\gamma-\gamma$ globulin; $s$-slow $\gamma$ globulin; $f-$ fast $\gamma$ globulin 
Acta Veterinaria (Beograd), Vol. 60, No. 2-3, 155-164, 2010.

Fratrić Natalija et al.: Electrophoretic and immunoelectrophoretic characteristics of

IgG as a constituents of PEG precipitable immune complexes in preruminant calves' sera

Immunochemical characteristics of IgG in the calves' blood sera and in the PEG precipitable IC. Agarose gel electrophoresis showed that the distribution of fast and slow serum $\gamma$ globulins changed with the age of the calves. Immunoelectrophoresis with antiserum to total bovine $\lg G$ and $\lg$ G1 was performed with an aim to define the molecular base of this heterogeneity (Figure 2).

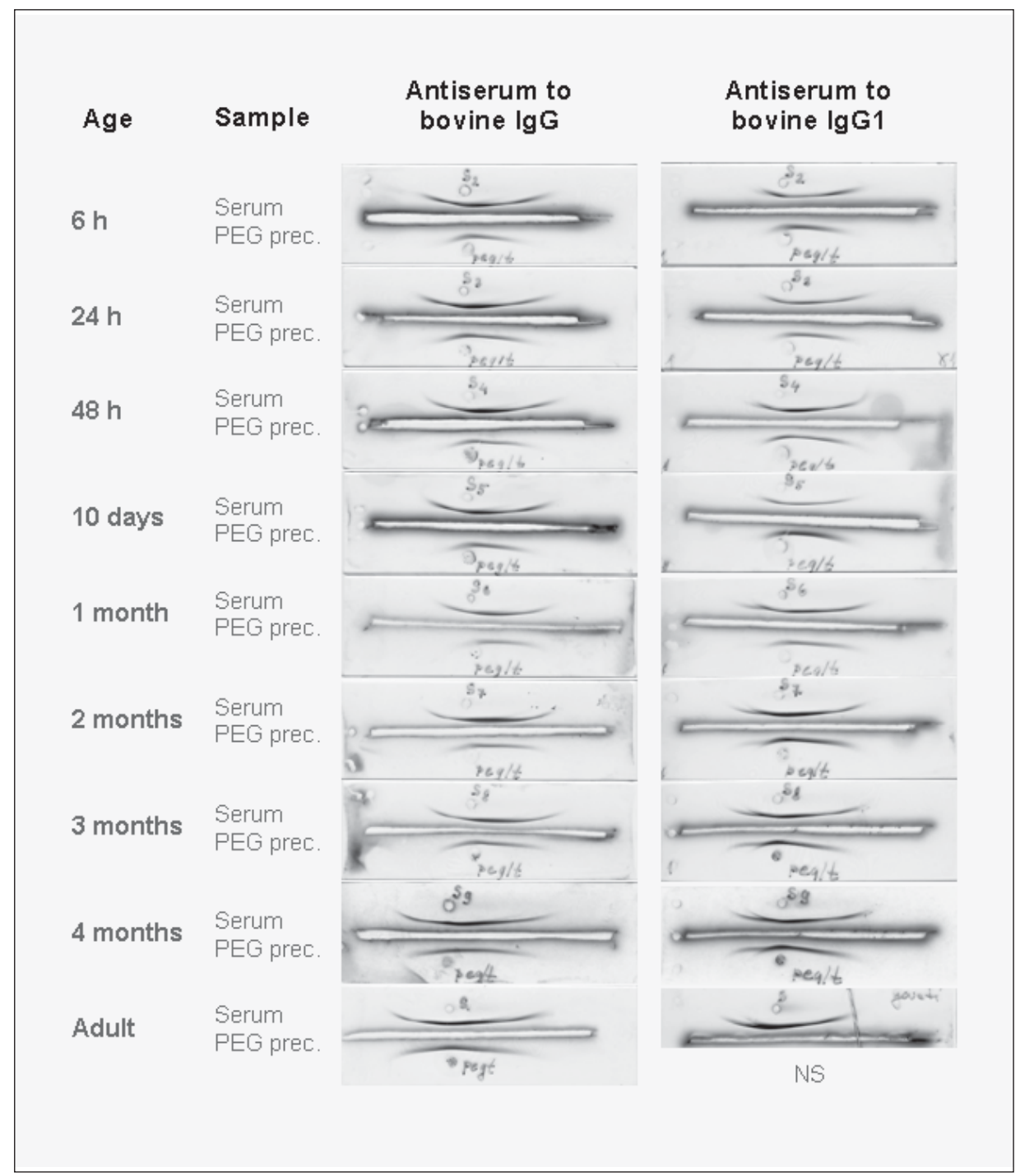

Figure 2. Immunoelectrophoresis of calves' sera and PEG precipitated IC performed with antisera to bovine IgG and IgG1. PEG prec.-PEG precipitated IC; NS - not shown 
The precipitation pattern in immunoelectrophoresis with antiserum to total bovine IgG showed that immunochemically heterogeneous IgG were detected in the sera of 6-hour old calves. The heterogeneity was manifested by bifurcation of the anodic part of the precipitation line and by elongation of its cationic part. Analysis performed with antiserum to bovine IgG1 subclass showed that immunochemical heterogeneity among IgG1 molecules was detected in the sera of 48-hour-old calves. The heterogeneity of IgG1 molecules was manifested by deformation of the anodic part of the precipitation line and bifurcation of its cationic part. This IgG1 molecule heterogeneity was less expressed in 10-day old calves' sera. In one-month old calves' sera, all molecular forms of IgG, present in adult cattle serum, were detected. These results showed that in the calves' sera, at least three immunochemically different groups of IgG molecules were detected. Among them, two are immunochemically identical, and one has partial immunochemical identity with them.

In all analyzed samples, IgG and IgG1 were identified in PEG precipitates of serum proteins. These IgG molecules belong to electrophoretically faster IgG molecules of IgG1 subclass. Analysis performed with antiserum to IgG1 subclass showed only one part of serum IgG1 molecules precipitated by PEG. These selective precipitations of some molecular forms of IgG1 molecules were noticed in 6-hour to one-month old calves. In older calves (two, three and four-months old), as well as in adult cattle, all molecular forms of serum IgG1 were precipitated by PEG.

\section{DISCUSSION}

In this study the PEG assay was used for the detection of IC in calves' sera. PEG precipitation is a simple method for quantitative determination of IC levels (Lock and Unsworth, 2000). It is known that PEG, beside immune-complexed immunoglobulins, also precipitates other serum proteins (Monay et al., 1983; Robinson et al., 1989) and therefore the PEG assay is considered as a nonspecific screening test for the presence of immune complexes (Lock and Unsworth, 2000; Nash and Davis, 2000). However, serum proteins are not denatured during PEG precipitations, and this method is still used for the isolation and in vitro studies of biological effects of immune complexes (Elshafie et al., 2007; Mathsson et al., 2007). Based on these data we decided to use this relatively simple assay that allows both the quantification of circulating immune complexes and the analyses of their composition.

Bovine IC in different age categories have not yet been studied in detail and data about physicochemical and immunochemical characteristics of IgG antibodies, as potential constituents of IC are rare. Results of measurements of serum PEG precipitable IC level (Fratrić et al., 2006), as well as our unpublished results on electrophoresis and immunoelectrophoresis, showed that immunecomplexed IgG cannot be detected in calf's serum before colostrum intake. Based on the fact that new born calves are agammaglobulinemic (Rajala and Castren, 1995), absence of circulating immune complexes before colostrum intake (Fratrić et al., 2006) was expected. OD values of PEG precipitates, as well as the intensity 
Acta Veterinaria (Beograd), Vol. 60, No. 2-3, 155-164, 2010.

Fratrić Natalija et al.: Electrophoretic and immunoelectrophoretic characteristics of

IgG as a constituents of PEG precipitable immune complexes in preruminant calves' sera

of $\gamma$ globulin fractions in sera and IC, have increased after colostrum ingestion, and continued to rise up to the 48th hour of age. Calves start with their own immunoglobulin synthesis in the forth week of life (Tizard, 1996), and in animals younger then one month, detected serum $\gamma$ globulin and IC could be passively transferred by colostrum (Archambault et al., 1988; Sato et al., 1990; Prosser et al., 1992; Rajala and Castren, 1995). Kilshaw and Slade (1981) detected the presence in the calves' sera of high avidity small molecular weight IC composed of maternal IgG and $\beta$ - or $\alpha$-lactoglobulin. These IC do not fix the complement system, and do not initiate inflammatory reactions and it has been assumed that IC composed of milk proteins can have an immunoregulatory function acting as specific immunosuppressors. In our study, for the first time, the presence PEG precipitable IC in preruminant calves' sera was described. It is known that PEG precipitate high (>19S) or intermediate (8 to 19S) molecular weight IC, whereas smaller IC could not be precipitated by PEG (Poulton et al., 1983). The role of this high molecular weight IgG containing IC is unclear. On the $10^{\text {th }}$ day the IC level and serum $\gamma$ globulin level (unpublished results) has decreased, and it may be due to the catabolism of immunoglobulins, and/or to a limited transport of milk proteins through the gut in this period (Prosser et al., 1992; Goldman, 1993; Weaver et al., 2000). Trend of increase in IC levels was evident in calves between one to four months of age. A positive correlation between the level of IC and some of the immunological parameters (serum immunoglobulin levels, auto antibodies etc.) in calves was previously described (Kilshaw and Slade, 1981; Heckert et al., 1991). Our results on immunoelectrophoresis showed that in one- to four months old cattle IC contained all molecular forms of IgG, normally present in adult cattle sera. In this period, maternal immunoglobulins are present in the calves' circulation only in traces (Banks and McGiure, 1989) and IC in these animals occurred most probably due to the capability of the calves' immune system to produce their own antibodies. At the age of one month, calves produce their own slow $\gamma$ globulins, but this fraction is not capable to form PEG precipitable IC. Occurrence of the slow $\gamma$ globulin fraction which contains IgG2 molecules (Butler, 1986), in sera and PEG precipitates in older calves, allows us to speculate that IgG2 molecules especially of the A2 allotype, which is not present in the sera of calves younger than three months (Corbeil et al., 1997), can be partly responsible for the increasing capacity of IgG molecules to form IC. IgG2 expressing A2 allotype is a very potent activator of complement by classical pathway (BastidaCorcuera, 1999) and it is important for the resistance to pyrogenic infections (Corbeil et al., 1997), but their capacity to form PEG precipitable IC in preruminant calves have not been studied yet.

In PEG precipitable IC from healthy bovine sera we have detected other serum proteins just like in PEG precipitable IC from sera of healthy people (Robinson et al., 1989; Nash and Davis, 2000). These non-immunoglobulin proteins can be the real element of IC or be co-precipitated by non-specific protein aggregation (Nash and Davis, 2000). Also, PEG precipitates could contain monomeric IgG in small amounts (Lock and Unsworth, 2000). This fact pointed the necessity for more detailed analyses of immunoglobulins and other constituents of IC in healthy calves. There is a number of ruminant diseases 
(infectious, autoimmune, neoplastic) that could be associated with elevated levels of pathological IC and the detection of such complexes and identification of their molecular constituents could be necessary for a precise detection, follow-up and the disease therapy.

\section{ACKNOWLEDGEMENTS}

This work was supported by the Ministry of Science and Technological Development of Republic of Serbia.

We would like to express our gratitude to Dr Irina Maslovaric for critical reviewing of this manuscript.

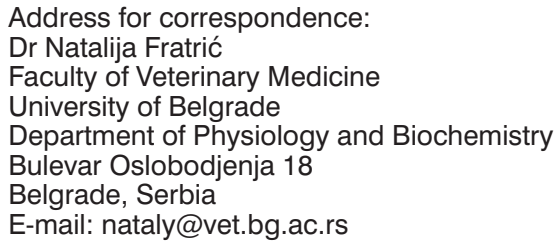

\section{REFERENCES}

1. Abbas AK, Lichman AH, Pober JS, 2007, Cellular and molecular immunology (6th edition), Saunders, Elsevier Comp, Philadelphia, PA.

2. Archambault D, Morin G, Elazhary Y, Roy RS, Joncas JH, 1988, Immune response of pregnant heifers and cows to bovine rotavirus inoculation and passive protection to rotavirus infection in newborn calves fed colostral antibodies or colostral lymphocytes, Am J Vet Res, 49, 1084-91.

3. Banks KL, McGiure TC, 1989, Neonatal immunology. In: Veterinary clinical immunology, ed. Halliwel REW, Gorman NT, pp. 197-200. WB Saunders Company Harcourt Brace Jovanovich, Philadelphia PA.

4. Bastida-Corcuera FD, Butler JE, Yahiro S, Corbeil LB, 1999, Differential complement activation by bovine IgG2 allotypes, Vet Immunol Immunopathol, 71, 115-23.

5. Butler JE, 1986, Biochemistry and biology of ruminant immunoglobulins, Prog Vet Microbiol Immunol, 2, 1-53.

6. Corbeil LB, Gogolewski RP, Kacskovics I, Nielsen KH, Corbeil RR, Morrill JL et al., 1997, Bovine IgG2a antibodies to Haemophilus somnus and allotype expression, Can J Vet Res, 61, 207-13.

7. Elshafie Al, Ahlin E, Mathsson L, EIGhazali G, Rönnelid J, 2007, Circulating immune complexes (IC) and IC-induced levels of GM-CSF are increased in Sudanese patients with acute visceral Leishmania donovani infection undergoing sodium stibogluconate treatment: Implications for disease pathogenesis, $J$ Immunol, 178, 5383-9.

8. Fratrić N, Milošević-Jovčić N, Ilić V, Stojić V, 2006, The levels of immune complexes in the blood sera of calves in neonatal period and adult cattle, Acta Veterinaria (Beograd), 56, 103-10.

9. Goldman AS, 1993, The immune system of human milk: antimicrobial, anti-inflammatory and immunomodulating properties, Pediatr Infect Dis J, 12, 664-71.

10. Heckert RA, Saif LJ, Myers GW, 1991, Mucosal and systemic isotype-specific antibody responses to bovine corona virus structural proteins in naturally infected dairy calves. Am J Vet Res, 52, 852-7.

11. Johansson BG, 1972, Agarose gel electrophoresis, Scand J Clin Lab Invest, 29 (Suppl.124), 7-9.

12. Kilshaw PJ, Slade $H, 1981$, Milk protein immune complexes in the cow and calf, J Reprod Immunol, 3, 227-36.

13. Korhonen H, Marnila P, Gill HS, 2000, Milk immunoglobulins and complement factors, Br J Nutr 84 , 75-80.

14. Lock RJ, Unsworth DJ, 2000, Measurement of immune complexes is not useful in routine clinical practice, Ann Clin Biochem, 37, 253-61. 
Acta Veterinaria (Beograd), Vol. 60, No. 2-3, 155-164, 2010.

Fratrić Natalija et al.: Electrophoretic and immunoelectrophoretic characteristics of

IgG as a constituents of PEG precipitable immune complexes in preruminant calves' sera

15. Mathsson L, Ahlin E, Sjöwall C, Skogh T, Rönnelid J, 2007, Cytokine induction by circulating immune complexes and signs of in-vivo complement activation in systemic lupus erythematosus are associated with the occurrence of anti-Sjögren's syndrome A antibodies, Clin Exp Immunol, 147, 513-20.

16. Monay NA, Hay FC, Poultion TA, 1983, A comparative study of complement components in polyethylene glycol precipitated immune complexes from patients with ovarian cancer and patients with rheumatoid arthritis, Clin Exp Immunol, 52, 561-8.

17. Nash JT, Davies KA, 2000, Complement and Immune Complexes. Methods Mol Biol, 150, 203-14.

18. Nikolić V, Živanović Lj, Stojić V, Vukotić M, 1981, The evaluation of some techniques for detection of circulating immune complexes in cattle serum, Acta Veterinaria (Beograd), 31, 205-12.

19. Nydegger UE, 2007, Immune complex patophysiology, Ann NY Acad Sci, 1109, 66-83.

20. Prosser CG, Eichler SJ, Farr VC, Davis SR, 1992, Effect of colostrum intake on alpha-lactalbumin concentrations in serum of calves, Res Vet Sci, 53, 219-22.

21. Poulton TA, Mooney NA, Nineham LJ, Hay FC, 1983, Characteristics of immune complexes detectable by two independent assays in gynaecological malignancies, Clin Exp Immunol, 53, 573-80.

22. Rajala $P$, Castren H, 1995, Serum immunoglobulin concentrations and health of dairy calves in two management systems from birth to 12 weeks of age, J Dairy Sci, 78, 2737-44.

23. Robinson MW, Scott DG, Bacon PA, Walton KW, Coppock JS, Scott DL, 1989, What proteins are present in polyethylene glycol precipitates from rheumatic sera? Ann Rheum Dis, 48, 496-501.

24. Sato S, Ogimoto K, Nakai Y, 1990, Detection of bovine antibodies to the outer membrane of ruminal Bacteroides succinogenes by enzyme-linked immunosorbent assay (ELISA), Nippon Juigaku Zasshi, 52, 29-34.

25. Scheidegger JJ, 1955, Une micromethode l'immunoelectrophorése, Int Arch Allergy, 7, 103-10.

26. Schifferli JA, Taylor RP, 1989, Physiological and pathological aspects of circulating immune complexes, Kidney Int, 35, 993-1003.

27. Tizard IR, 1996, Veterinary immunology: An introduction. WB Saunders Comp. PhiladelphiaLondon-Toronto.

28. Weaver DM, Tyler JW, VanMetre DC, Hostetler DE, Barrington GM, 2000, Passive transfer of colostral immunoglobulins in calves, J Vet Intern Med, 14, 569-77.

\title{
ELEKTROFORETSKE I IMUNOELEKTROFORETSKE KARAKTERISTIKE IgG KAO KONSTITUENATA PEG PRECIPITABILNIH IMUNOKOMPLEKSA SERUMA KOD TELADI DO ČETVRTOG MESECA STAROSTI
}

\author{
FRATRIĆ NATALIJA, ILIĆ VESNA, MILOŠEVIĆ-JOVČIĆ NADEŽDA i STOJIĆ V
}

\section{SADRŽAJ}

Telad od rođenja dolazi u kontakt sa velikim brojem antigena za čije je efikasno uklanjanje neophodno formiranje imunokompleksa. Sposobnost ovih, još uvek imunološki nezrelih, životinja da formiraju iminokomplekse, kao i sastav njihovih konstituenata, nisu detaljno ispitivani. U ovom radu smo imunokomplekse iz seruma teladi izolovali precipitacijom polietilen glikolom (PEGom), a osobine IgG, kao potencijalnih konstituenata imunokompleksa, analizirali metodama elektroforeze i imunoelektroforeze. $U$ našem prethodnom radu dokazali smo da se 
nivo PEG precipitabilnih imunokompleksa menja sa uzrastom teladi. On raste od rođenja do 48. sata, opada desetog dana, ponovo raste u prvom mesecu, nakon čega ostaje nepromenjen do četvrtog meseca starosti. Elekroforetske i imunoelektroforetske analize su ukazale da se u serumu i PEG precipitatima seruma teladi do mesec dana starosti nalazi samo jedna molekulska frakcija lgG koja odgovara brzim, anjonskim IgG. lako se u serumima teladi već u prvom mesecu starosti nalaze sve molekulske forme lgG koje se nalaze i u serumu odraslih krava, samo jedan njihov deo (brzi, anjonski $\gamma$ globulini) ima sposobnost da formira imune komplekse. Kod starijih teladi, kao i kod odraslih krava, sve molekulske forme serumskih IgG mogu da formiraju imune komplekse. Ovi rezultati, zajedno sa rezultatima našeg predhodnog rada, se mogu koristiti za dobijanje referentnog sistema vrednosti nivoa i sastava imunokompleksa kod zdravih teladi, a koji bi se mogao koristiti za određivanje nivoa i sastava imunokompleksa kod teladi u patološkim uslovima. 